\title{
POLLEN PRODUCTIVITY AND MORPHOLOGY OF POLLEN GRAINS IN TWO CULTIVARS OF HONEYBERRY (LONICERA KAMTSCHATICA (SEVAST.) POJARK.)
}

\author{
Małgorzata Bożek \\ Department of Botany Agricultural University of Lublin, ul. Akademicka 15, 20950 Lublin \\ e-mail: malgorzata.bozek@ar.lublin.pl
}

Received: 02.05.2007

\section{$\mathrm{S}$ u $\mathrm{m} \mathrm{m}$ a r y}

In the years 2004 2006, investigations on the abundance of pollen production in two cultivars of Lonicera kamtschatica (Sevast.) Pojark. Atut and Duet, were conducted at the Felin Experimental Farm of the Agricultural University in Lublin. Moreover, the viability of pollen grains was estimated and me asurements of their size were taken. Ten flowers of both studied cultivars supplied $11.42 \mathrm{mg}$ of pollen and the average pollen pro ductivity per 1 ha of a several years old plantation was $30.04 \mathrm{~kg}$. The pollen of the observed plants was eagerly collected by ho ney bees. Pollen grains of both cultivars are suboblate. Conside ring their size, they can be described as large ones (P $47.55 \mu \mathrm{m}$, E $60.37 \mu \mathrm{m}$ ). Pollen viability for both cultivars is high, about $95 \%$.

Key words: honeyberry, Lonicera kamtschatica, pollen produc tion

\section{INTRODUCTION}

Honeyberry (Lonicera kamtschatica (Sevast.) Pojark.) berries ripe earlier than other fruits grown in orchards. Blooming of this species starts usually in the second half of April and finishes about the middle of May, coinciding with the period of high pollen demand by bee colonies. The aim of the present study was to estimate pollen productivity in two cultivars of L. kamtschatica, in the conditions of south-eastern Poland. Moreover, the viability and size of pollen grains in both cultivars were investigated.

\section{MATERIAL AND METHODS}

The study was carried out in 2004-2006 at the Felin Experimental Farm of the Agricultural University in Lublin. Two cultivars of Lonicera kamtschatica (Sevast.) Pojark. - Atut and Duet were observed. The shrubs were planted in 2-row strips, in spring 2001. The distance between the plants in one row was $1 \mathrm{~m}$ and between the strips $-1.2 \mathrm{~m}$. The experiment was established on gray-brown soil which originated from medium heavy clay. The mechanical composition of the soil is typical for slightly acid, light silty clays.

The abundance of pollen produced by flowers was determined by the ether method (Warak omska, 1972), modified by Szklanowska (Szklanowska and Pluta, 1984; Szklanows ka, 1995). Flowers for pollen samples were collected just before corolla opening, 3 times during the blooming period. Each time 4 samples were gathered. A single sample contained 50 mature anthers. Pollen viability was checked in standard semi-permanent slides stained with acetocarmine. Measurements of the length of the equatorial and polar axis were taken in equatorial view of pollen grains, mounted in glycerin-jelly slides. As regards the shape and size, pollen grains were classified according to Erdtman (1956). Pollen prepared for examination and photographs in SEM was not treated with acetolysis.

To evaluate the abundance of flowering, each year freshly opened flowers were marked and counted on a randomly chosen branch of eight shrubs of the investigated cultivars. The counting was performed every 2-3 days during the blooming period. Then, the number of branches per each shrub was determined and the flower number per plant was calculated.

The data were analyzed by two-way ANOVA followed by Duncan test at $\alpha=0.05$.

\section{RESULTS}

In the season 2004 and 2005, in the climatic conditions of Lublin, flowering of Lonicera kamtschatica occurred between 20 April and the middle of May. In late spring 2006, blooming of the shrubs started at the end of April and lasted until 18 May. 
Flowers of Lonicera kamtschatica are protandrous. When flowers open in the morning, pollen starts to be exposed in the afternoon hours, whereas flowers opened in the evening start to release pollen the next day, before noon. The anthers in 5 stamens dehisced one by one. The process of pollen release lasted until the second or even third day of flower life, depending on the time of flower bud opening and the weather conditions. During dry and sunny weather, the flower life-span lasted 3-4 days.

Pollen grains of two cultivars studied are similar in size; however, in cv. Ducat the equatorial axis is significantly longer than in cv. Atut (Tab. 1). The equatorial axis of $\mathrm{cv}$. Atut pollen grains, the longer axis, ranged from 50 to $70 \mu \mathrm{m}$, on average $-59.77 \mu \mathrm{m}$. In the case of cv. Duet, the values were 45.25-71.25 $\mu \mathrm{m}$ and 61.46, respectively. The length of the polar axis for cv. Atut was in the range of 37.5-57.5 $\mu \mathrm{m}$ (mean $47.64 \mu \mathrm{m})$ and for cv. Ducat 40.0-58.75 $\mu \mathrm{m}(47.46 \mu \mathrm{m})$, respectively. The range of $\mathrm{P} / \mathrm{E}$ ratio, describing the shape of grains, was similar in both cultivars and it was $0.72-0.89$. The mean for cv. Atut was 0.81 and 0.77 for cv. Duet (Tab. 1).
With such values of $\mathrm{P} / \mathrm{E}$ ratio, pollen grains of both cultivars can be described as suboblate. In the case of $\mathrm{cv}$. Atut, the mean percentage of suboblate pollen grains was 83.89 , whereas the relative abundance of oblate and oblate-spheroidal grains was $8.05 \%$ each (Tab. 2). In the cultivar Duet, the average percentage of suboblate, oblate and oblate-spheroidal pollen grains was: 70.28 , $27.5,2.2$, respectively. In polar view, the shape of the pollen outline was convexo-tetragonal, sometimes almost square. In equatorial view, that shape was more or less oblate. The 4-aperturate pollen grains were the most common in the samples, but also sparse grains with five and three apertures were present there. The pollen viability in both the cultivars studied was high $-95.63 \%$ (Tab. 1)

The average mass of pollen obtained from flowers differed significantly between the cultivars and the amount of pollen produced in anthers did show a year effect within the cultivars (Tab. 3). The cultivar Duet was a better pollen producer than the cultivar Atut. Ten flowers of the first cultivar supplied $12.12 \mathrm{mg}$ of pollen, whereas the same number of florets of the second

Table 1

Pollen grain size, shape and viability in two cultivars of Lonicera kamtschatica (Sevast.) Pojark.

\begin{tabular}{|c|c|c|c|c|c|c|c|}
\hline \multirow{3}{*}{ Cultivar } & \multirow{3}{*}{ Year } & \multicolumn{4}{|c|}{ Axis length $(\mu \mathrm{m})$} & \multirow{3}{*}{$\begin{array}{c}\text { Shape } \\
\text { P/E }\end{array}$} & \multirow{3}{*}{ Viability $\%$} \\
\hline & & \multicolumn{2}{|c|}{ Polar (P) } & \multicolumn{2}{|c|}{ Equatorial (E) } & & \\
\hline & & $\min . \max$ & average & $\min . \max$ & average & & \\
\hline \multirow[t]{2}{*}{ Atut } & $\begin{array}{l}2004 \\
2005 \\
2006\end{array}$ & $\begin{array}{l}42.5050 .00 \\
37.5057 .50 \\
40.0055 .00\end{array}$ & $\begin{array}{l}46.38_{\mathrm{a}} \\
49.22_{\mathrm{b}} \\
47.33_{\mathrm{a}}\end{array}$ & $\begin{array}{l}52.5065 .00 \\
50.0067 .50 \\
52.5070 .00\end{array}$ & $\begin{array}{l}58.32_{\mathrm{a}} \\
58.72_{\mathrm{ab}} \\
60.78_{\mathrm{c}}\end{array}$ & $\begin{array}{l}0.80 \\
0.84 \\
0.78\end{array}$ & $\begin{array}{l}90.67 \\
98.25 \\
98.42\end{array}$ \\
\hline & average & 37.5057 .50 & $47.64_{\mathrm{A}}$ & 50.0070 .00 & $59.27_{\mathrm{A}}$ & 0.81 & 95.78 \\
\hline \multirow[t]{2}{*}{ Duet } & $\begin{array}{l}2004 \\
2005 \\
2006\end{array}$ & $\begin{array}{l}42.5058 .75 \\
40.0057 .50 \\
40.0057 .50\end{array}$ & $\begin{array}{l}47.13_{\mathrm{a}} \\
47.71_{\mathrm{a}} \\
47.54_{\mathrm{a}}\end{array}$ & $\begin{array}{l}56.2567 .50 \\
46.2570 .00 \\
52.5071 .25\end{array}$ & $\begin{array}{l}61.79_{c} \\
60.48_{b c} \\
62.10_{c}\end{array}$ & $\begin{array}{l}0.76 \\
0.79 \\
0.77\end{array}$ & $\begin{array}{l}91.58 \\
96.41 \\
98.42\end{array}$ \\
\hline & average & 40.0058 .75 & $47.46_{\mathrm{A}}$ & 46.2571 .25 & $61.46_{\mathrm{B}}$ & 0.77 & 95.47 \\
\hline \multicolumn{2}{|c|}{ Average for cultivars } & 37.5958 .75 & 47.55 & 46.2571 .25 & 60.37 & 0.79 & 95.63 \\
\hline
\end{tabular}

\footnotetext{
${ }^{*}$ means followed by the same letters are not significantly different at $\alpha 0,05$
} 
Table 2

Relative abudance of different shaped pollen grains, according to $\mathrm{P} / \mathrm{E}$ ratio, in two cultivars of Lonicera kamtschatica (Sevast.) Pojark.

\begin{tabular}{|c|c|c|c|c|}
\hline \multirow{2}{*}{ Cultivar } & \multirow{2}{*}{ Year } & \multicolumn{3}{|c|}{ Percentage of different shaped pollen grains } \\
\hline & & $\begin{array}{c}\text { oblate } \\
(4 / 96 / 8)\end{array}$ & $\begin{array}{c}\text { suboblate } \\
(6 / 87 / 8)\end{array}$ & $\begin{array}{l}\text { oblate spheroidal } \\
\quad(7 / 88 / 8)\end{array}$ \\
\hline \multirow[t]{2}{*}{ Atut } & $\begin{array}{l}2004 \\
2005 \\
2006\end{array}$ & $\begin{array}{r}7.50 \\
3.33 \\
13.33\end{array}$ & $\begin{array}{l}92.50 \\
73.33 \\
85.83\end{array}$ & $\begin{array}{r}23.33 \\
0.83\end{array}$ \\
\hline & average & 8.05 & 83.89 & 8.05 \\
\hline \multirow[t]{2}{*}{ Duet } & $\begin{array}{l}2005 \\
2005 \\
2006\end{array}$ & $\begin{array}{l}35.00 \\
17.50 \\
30.00\end{array}$ & $\begin{array}{l}62.50 \\
78.33 \\
70.00\end{array}$ & $\begin{array}{l}2.50 \\
4.17\end{array}$ \\
\hline & average & 27.50 & 70.28 & 2.20 \\
\hline
\end{tabular}

Table 3

Abundance of blooming and pollen yield of flowers in two cultivars of Lonicera kamtschatica (Sevast.) Pojark. in 20042006 in Lublin.

\begin{tabular}{|c|c|c|c|c|c|c|}
\hline \multirow{2}{*}{ Cultivar } & \multirow{2}{*}{ Year } & \multirow{2}{*}{$\begin{array}{c}\text { Average } \\
\text { number of } \\
\text { flowers per } \\
\text { shrub }\end{array}$} & \multicolumn{2}{|c|}{$\begin{array}{l}\text { Mass of pollen amount } \\
\text { per } 10 \text { flowers }(\mathrm{mg})\end{array}$} & \multicolumn{2}{|c|}{ Pollen efficiency per } \\
\hline & & & $\min . \max$. & average SD & 1 shrub $(g)$ & 1 ha $(\mathrm{kg})$ \\
\hline \multirow{4}{*}{ Atut } & 2004 & 2578.18 & 7.412 .3 & $10.38_{\mathrm{ab}} \pm 2.24$ & 2.68 & 21.44 \\
\hline & 2005 & 3453.79 & 7.911 .7 & $9.62 \pm 1.22$ & 3.32 & 26.56 \\
\hline & 2006 & 3589.13 & 9.915 .8 & $12.15_{b} \pm 2.16$ & 4.36 & 34.80 \\
\hline & average & 3207.03 & 7.415 .8 & $10.72_{\mathrm{A}} \pm 2.13$ & 3.45 & 27.60 \\
\hline \multirow{4}{*}{ Duet } & 2004 & 2477.25 & 6.811 .3 & $8.75_{\mathrm{a}} \pm 1.99$ & 2.17 & 17.36 \\
\hline & 2005 & 3277.20 & 7.714 .3 & $12.07 \mathrm{~b} \pm 2.80$ & 3.96 & 31.68 \\
\hline & 2006 & 3892.50 & 14.517 .6 & $15.55_{\mathrm{c}} \pm 0.97$ & 6.05 & 48.40 \\
\hline & average & 3215.65 & 6.817 .6 & $12.12_{\mathrm{B}} \pm 3.13$ & 4.06 & 32.48 \\
\hline \multicolumn{2}{|c|}{ Average for cultivars } & 3211.34 & & 11.42 & 3.76 & 30.04 \\
\hline
\end{tabular}

${ }^{*}$ means followed by the same letters are not significantly different at $\alpha=0,05$

one $-10.72 \mathrm{mg}$. The mean pollen productivity in $\mathrm{cv}$. Duet varied widely in the consecutive years of study and is from 8.75 to $15.55 \mathrm{mg}$. For cv. Atut, the values ranged between 9.62 and $12.15 \mathrm{mg}$. The estimated average pollen amount obtained from 1 ha plantation of cvs Atut and Duet was 27.6 and $32.48 \mathrm{~kg}$, respectively. Observed in the following years of the experiment, an increase in pollen productivity in both cultivars was due to the growth of plants and, in consequence, to a growing abundance of their flowering. It was also caused by the variability of pollen mass produced by flowers in the consecutive years of study. Among insects working on the honeyberry plantation, honey bees, bumblebees and, occasionally, solitary bees were present. Numerous honey bee workers collected both nectar and pollen. The insects formed dingy yellow pollen loads. 

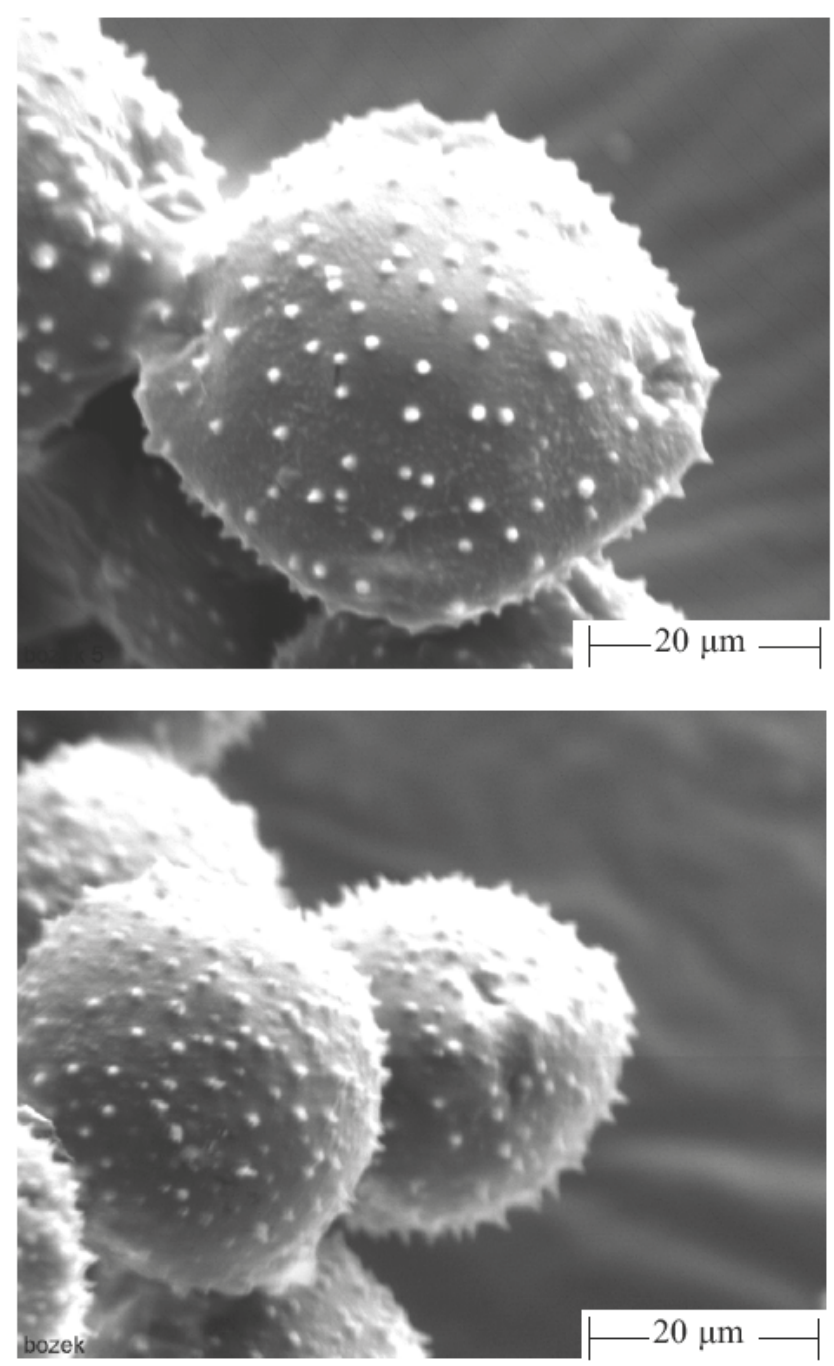

Fig. 1. Pollen grains of Lonicera kamtschatica (Sevast.) Pojark. cv. Atut in different position view (SEM).

\section{DISCUSSION}

Some species of Lonicera are mentioned among valuable, melliferous plants (Szklanowska, 1978; Jabłońs ki and Kołt owski, 2000). Also, the studied Lonicera kamtschatica is an attractive source of nectar (Bożek and Wieniarska, 2006) and pollen reward for honey bees. Pollen of this plant, highly viable-about $95 \%$, has a great nutritive value for insects. The amount of pollen produced by 10 flowers of Lonicera kamtschatica - $11.42 \mathrm{mg}$, obtained in the present study, was almost double the mass reported for Lonicera tatarica $-5.43 \mathrm{mg}$, by Warakom ska (1972). The increase in pollen mass produced by 10 flowers, especially significant in 2006, was probably due to an enlargement of the size of anthers - in this year the highest mass of fresh anthers was noted.
Lonicera type pollen grains are zonocolpate, more or less spheroidal - oblate (Erdtman, 1956), echinate or microechinate (Moore at al. 1991). Moo re et al. (1991) described Lonicera coerulea pollen as tetrazonocolpate or tetrazonocolporate, sometimes 3 -aperturate. They also reported that those grains were with very short, narrow colpi and large apocolpia, each colpus crossed by a short, very wide transverse endocolpus. In the examined samples of Lonicera kamtschatica, the 4-aperturate pollen grains were the most abundant, however scarce 3- and 5- aperturate grains were found. Riccardelli (1998) recognized Lonicera pollen grains as large ones. According to Erdtman (1956), the length of the longer axis was in the range $30-80 \mu \mathrm{m}$. Similar values were obtained for two cultivars of Lonicera kamtschatica in the present study. For both cultivars, the length of the polar axis $(\mathrm{P})$ ranged between 37.5-58.75 $\mu \mathrm{m}$ (47.55 $\mu \mathrm{m}$, on average), whereas the length of the equatorial axis (E) was 46.25-71.25 $\mu \mathrm{m}(60,37 \mu \mathrm{m}$, on average). According to Erdtman (1956), pollen grains of that size should be classified as large ones.

\section{CONCLUSIONS}

1. In protandrous flowers of Lonicera kamtschatica, anthers start to shed pollen a few hours after the opening of corolla.

2. Ten flowers of the investigated cultivars of honeyberry supply $11.42 \mathrm{mg}$ of pollen and the mean calculated pollen productivity per 1 ha of several-year-old plantation is $30.04 \mathrm{~kg}$.

3. In both cultivars, pollen grains are suboblate, and considering their size, they can be classified as large ones (mean values of $\mathrm{P}=47.55 \mu \mathrm{m}$ and $\mathrm{E}=60.37 \mu \mathrm{m}$ ); their viability is high - about $95 \%$.

4. Pollen produced in flowers of Lonicera kamtschatica is eagerly collected by honey bees.

\section{REFERENCES}

Bożek M., Wieniarska J. 2006. Biologia kwitnienia i wy dajność cukrowa kwiatów dwóch odmian Lonicera kamtschatica (Sevast.) Pojark.). / Biology of flowering and sugar yield of flower sof two cultivars Lonicera kamtschatica (Sevast.) Pojark.). Acta Agrobot. 59, 1: 177182.

Erdtman G., 1956. Morfologija pylcy i sistematika rastienij. Iz datelstwo Inostrannoj Literatury, Moskva.

Jabłoński B., Kołtowski Z., 2000: Nektarowanie i wydaj ność miodowa roślin miododajnych w warunkach Polski. Część IX. / Nectar production and honey yield of mel liferous plants in the conditions of Poland. Part IX. Pszc zeln. Zesz. Nauk. 44(1): 205211.

Moore P. D., Webb J. A., Collinson M. E. 1991 Pollen Analysis. Second Edition. Blackwell Scientific Publica tions. Oxford. 
Ricciardelli D'Albore. 1998. Mediterranean melissopaly nology. Ed. Univ. degli studi di Perugia, Fac. di Agraria, Perugia, 466 pp.

Szklanowska K., 1978.: Nektarowanie i wydajność miodo wa niektórych drzew i krzewów w warunkach Polski. / Nectar production and honey yield of certain trees and shrubs in the conditions of Poland. Pszczeln. Zesz. Nauk. 22: 117127.

Szklanowska K., 1995. Pollen flows of crowfoot family (Ranunculaceae L.) from some natural plant communities. In: Changes in Fauna of Wild Bees In Europe. Pedagogi cal Univ., Bydgoszcz: 201214.

Szklanowska K., Pluta S., 1984. Wydajność pyłkowa sadu wiśniowego odmian Kerezer, Nefris, Łutówka, / Pollen yield of a cherry orchard with cherry cultivars Kerezer, Nefris, Łutówka. Pszczeln. Zesz. Nauk. 28: 6390.

Warakomska Z., 1972: Badania nad wydajnością pyłkową ro ślin. / Studies on pollen yield of plants. Pszczeln. Zesz. Nauk. 16: 6390 .

\section{Wydajność pyłkowa i morfologia ziarn pyłku dwóch odmian suchodrzewu kamczackiego (Lonicera kamtschatica (Sevast.) Pojark.)}

\section{Streszczenie}

Doświadczenia nad obfitością pylenia kwiatów dwóch odmian Lonicera kamtschatica (Sevast.) Pojark.: 'Atut' i 'Duet', prowadzono w latach 2004-2006 w Lublinie w Gospodarstwie Doświadczalnym AR - Felin. Zbadano także żywotność i wykonano pomiary wielkości ziaren pyłku. Kwiaty badanych roślin wytwarzały 11,42 mg pyłku z 10 kwiatów, a przeciętna wydajność pyłkowa $\mathrm{z} 1$ ha kilkuletniej plantacji dla obu odmian wynosiła $30,04 \mathrm{~kg}$ pyłku. Pyłek był chętnie zbierany przez pszczoły miodne. Ziarna pyłku obu odmian posiadają kształt lekko spłaszczony (suboblate), pod względem wielkości należą do dużych $(\mathrm{P}=47,55 \mu \mathrm{m}, \mathrm{E}=60,37 \mu \mathrm{m})$ i charakteryzuja się wysoką żywotnością w granicach $95 \%$. 
